\title{
A comparison of copied morphemes in Sakha (Yakut) and Éven ${ }^{1}$
}

\section{Introduction}

\subsection{Borrowing scales}

As reflected in the variety of 'borrowing scales' that have been set up in the literature (see Matras 2009: 153-165 for an overview), it is widely accepted that there are differences in the ease with which items are copied from one language to another. There is a general consensus that nouns are most easily copied, whereas bound morphology is the least prone to copying. Within bound morphology, a distinction can be made between derivational and inflectional morphology, with the latter bringing up the rear in all copyability scales (Wilkins 1996: table 14.2). (However, as demonstrated by Robbeets [this volume], a distinction should be made between category-retaining and category-changing derivation, especially denominal verbalizers, with the latter being cross-linguistically very rare.) Nevertheless, while the copying of bound morphemes is indeed far less common than the copying of lexemes, it is by now a well-documented outcome of language contact. In particular, several cases are known in which not only derivational but also inflectional affixes have been copied (e.g. Heath 1978; Gardani 2008, 2012; Grant 2008; Seifart 2012).

The reason for the resistance of bound morphology to processes of copying is often implied to be the tight integration of such affixes with the lexical material of the model language, which makes them more difficult to perceive as a separate entity. Backus and Verschik (2012), however, argue that it is less the bound nature than the very general meanings of such items that make them hard to copy. They suggest that the copying of specific meanings leads to the copying of overt forms,

\footnotetext{
1 This work was begun while I was still at the MPI for Evolutionary Anthropology in Leipzig, Germany, and was presented at the workshop "Bound morphology in common: copy or cognate?" at the 43rd annual meeting of the SLE in Vilnius in September 2010. The Sakha corpus was collected with financial assistance of the Wenner-Gren Foundation for Anthropological Research, Inc. and the MPI for Evolutionary Anthropology. The Lamunkhin Ėven data was collected with financial assistance of the Max Planck Society (via the MPRG on Comparative Population Linguistics) and the Volkswagen Foundation (via a DoBeS project on the cultural and dialectal diversity of Ėven).
} 
while the copying of general meanings tends to lead to the copying of patterns rather than forms: "[S]emantic specificity should be viewed as a continuum with content items on one end, grammatical markers on the other, and many other things [...] in-between. The more an element is located towards the specific end of this continuum, the more copyable it is, because there is unlikely to be a native element that matches its semantics completely" (Backus and Verschik 2012: 139). Furthermore, they suggest that the more prominent a feature is at the level of discourse pragmatics, the higher are its chances of being copied as an overt form (Backus and Verschik 2012: 130). Seifart (2012) suggests a further factor that might play a role in morphological copying: the Principle of Morphosyntactic Subsystem Integrity (PMSI), which states that copied morphemes are more likely to stem from paradigmatically and syntagmatically interrelated subsystems than from isolated domains.

The factors suggested as facilitating the copying of morphemes (Weinreich 1953: 31-37; Heath 1978: 105-107, 110; Backus and Verschik 2012; Seifart 2012) can be summarized as follows (where '>' signifies 'are more likely to result in copies'):

(1) Factors facilitating the copying of morphemes:

b) congruent structures (formal + functional similarity of morphemes) > divergent structures

c) phonologically salient + syllabic (independently pronounceable) morphemes > phonologically reduced/non-syllabic morphemes

d) sharp boundaries (stem occurs in isolation as well as with morphemes) > fuzzy boundaries

e) unifunctional morphemes $>$ multifunctional morphemes $>$ portmanteau morphemes

f) categorially clear (i.e. function of morpheme is clear in itself without recourse to other morphemes or context) > categorially opaque

g) specific meaning of morphemes $>$ general meaning of morphemes

h) affective meaning/pragmatic salience of morphemes $>$ no affective meaning of morphemes

i) morphosyntactically (paradigmatically and syntagmatically) interrelated morphemes > individual, unconnected morphemes

From this schema one can set up the hypothesis that if the model and recipient languages are structurally congruent, and if they have phonologically salient and syllabic, sharply bounded, relatively unifunctional, categorially clear morphology rather than phonologically reduced, fuzzily bounded, categorially opaque portmanteau morphemes, then affixes could be copied from the model to the recipient language. Furthermore, in such a case it is more likely that the copied 
morphemes will be derivational rather than inflectional, and that they will have a specific, pragmatically salient meaning (with a "high meaning potential", i.e. a relatively high contribution to the meaning of an utterance, Backus and Verschik 2012: 140) rather than a very general meaning. Lastly, the copied morphemes are expected to form paradigmatically or syntagmatically related subsystems rather than coming from various different domains of the grammar.

In this paper, I explore these hypotheses and, taking into account molecular anthropological data, consider further factors that might affect the outcome of morphological copying. I do this by contrasting two case studies that involve typologically similar languages involved in sociolinguistically similar contact situations: the Turkic language Sakha (Yakut), which was in intense contact with Mongolic languages, and the Lamunkhin dialect of the Tungusic language Ėven, which is still in intense contact with Sakha. In the following, I briefly introduce the two contact situations (Section 1.2) and discuss some methodological issues (Section 1.3) before turning to a description and discussion of the data (Section 2 and 3). Section 4 discusses the findings in the light of the hypotheses set up above, and Section 5 concludes the paper.

\subsection{The languages and contact situations}

\subsubsection{Sakha (Yakut)}

Sakha (also known as Yakut) is a divergent Turkic language spoken in the Republic Sakha (Yakutia) in northeastern Siberia (see map) by approximately 450,000 people (Russian census 2010), most of whom are small-scale horse and cattle breeders living in rural settlements. Irrespective of the enormous territory in which Sakha is spoken, it is a very homogenous language with few dialects and minor differences between regional varieties. This homogeneity can possibly be explained by the recent expansion of the language: on the basis of archaeological and genetic data (Gogolev 1993: 61, 88f; Alekseev 1996: 46; Pakendorf et al. 2006), it is estimated that the ancestors of the Sakha migrated from the vicinity of Lake Baikal in the 13th to 14 th century CE to a fairly restricted area on the middle Lena. Only in the 17th to 18th century CE did they expand further under pressure of Russian colonization to cover their current territory. This may not have been sufficient time for regional differences to accumulate.

Like other Turkic languages, Sakha is an agglutinative language with quite strict SOV word order and a large amount of derivational and inflectional, practically exclusively suffixing, morphology. With the exception of the possessive case paradigm, where possessor and case are fused into one suffix, morphemes are 


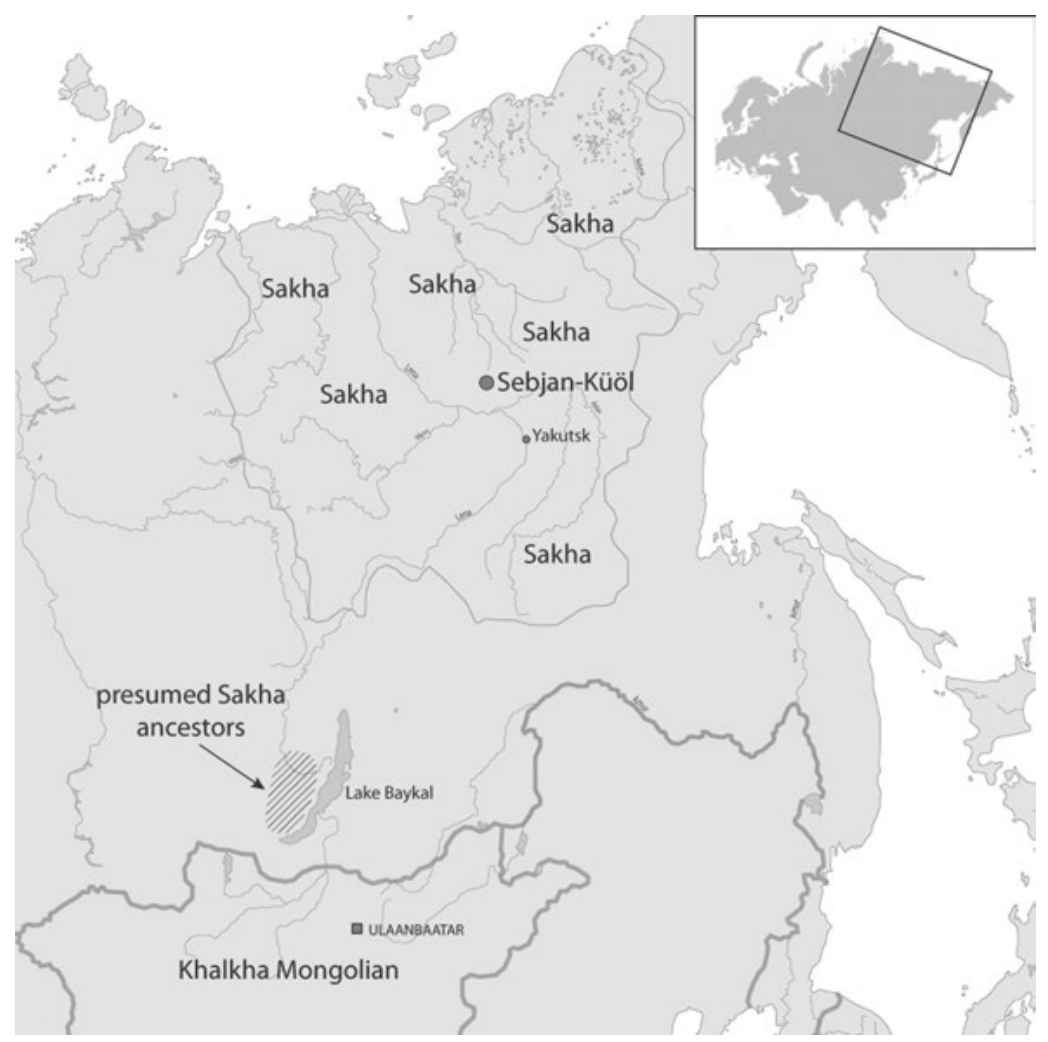

Map drawn by C. Fressard showing the location of the languages discussed in the text as well as the presumed area of settlement of the Sakha ancestors. Sebjan-Küöl is the village where Lamunkhin Ėven is spoken.

easily identifiable and separable, even though the surface form of both roots and suffixes changes due to vowel harmony and consonant assimilation across morpheme boundaries. Mongolic languages, too, are SOV and agglutinative, with a large number of inflectional and derivational suffixes, the surface forms of which are likewise affected by vowel harmony processes. In both languages, the nominative case is unmarked, so that bare noun stems occur frequently; bare verb stems express the imperative 2sG.

Even though nowadays the Sakha are settled at a great distance from Mongolia and no-one speaks or understands Mongolian anymore, their ancestors must have been in close contact with Mongols. This is shown by the large number of copied lexemes from Mongolic languages that are found in the language today: approximately $13 \%$ of $~ 1,400$ items included in the "Loanword Typology" database are of Mongolic origins (Pakendorf and Novgorodov 2009: 509). This number 
might, however, be an underestimate, with other estimates reaching 30-40\% (cf. Pakendorf 2007: 295). No single Mongolic model language is identifiable among the modern Mongolic languages (Kałużyński 1962: 122, 126). This provides an indication of the probable time of contact and thus some idea about the sociolinguistic aspects of the contact situation, about which we have no historic records: The Mongolic languages were unified into one single language when Genghis Khan united the Mongol tribes at the turn of the 12th to 13th centuries CE (Janhunen 1998: 203); from this unified language (called Middle Mongolian) the current diversity of the language family developed through subsequent geographic dispersal and contact with speakers of different languages. The fact that no single modern Mongolic language can be identified as the source of the Sakha lexical copies might thus indicate that the contact between the Sakha ancestors and the speakers of Mongolic languages took place when the Mongolic languages were still not distinct; this would place the time of contact before the Sakha migration to the north, i.e. before the 13th-14th century, making it plausible that the Sakha ancestors were in contact with the Mongols at the height of Mongolic power (Kałużyński 1962: 119-120). The nature of the copied items provides a further indication that the Mongols were in a socially dominant position (Pakendorf 2007: 296). For example, terminology pertaining to law and order are copied from Mongolic, as are terms for "concubine" or "servant". A particularly striking example is noxo', the Sakha term of address for a younger or lower-standing male, which was copied from Mongolic noxoj 'dog'.

\subsubsection{Lamunkhin Ėven}

Ėven is a dialectally highly fragmented North Tungusic language with $~ 13$ dialects belonging to two larger dialectal groups (eastern and western; Burykin 2004: 85) spoken in an extensive territory in northeastern Siberia. Mutual intelligibility is quite low between peripheral dialects due to differences in phonology, morphology, syntax, and lexicon. Here, I focus on the Lamunkhin dialect spoken in the village of Sebjan-Küöl in the Verkhoyansk mountain range of Yakutia (see map). This is the westernmost still viable Ėven dialect, with an estimated number of about 300 speakers, including small children.

Similar to Sakha and Mongolian, Ėven is an agglutinative language. While word order is somewhat free in the eastern dialects (and tends towards SVO in the Bystraja dialect spoken in central Kamchatka), it is fairly consistently verb-final in the Lamunkhin dialect. Like Sakha, Ėven has a large number of inflectional and derivational suffixes, which change their surface form according to rules of vowel harmony and consonant assimilation, and bare noun stems function as the nominative case form. In contrast to Sakha, however, bare verb stems do not occur in Ėven. 
Currently, the Sakha are the numerically and sociopolitically dominant indigenous group in Yakutia, and this holds for the situation in Sebjan-Küöl as well. Practically all speakers of Lamunkhin Ėven also speak Sakha (with the exception of very small children who do not go to kindergarten) as well as Russian. In public life, Sakha is widely used (e.g. in the village administration, in school, in shops), and there is a tendency to use Sakha as soon as an indigenous interlocutor is present who does not understand Ėven. It is thus not surprising that Lamunkhin Ėven shows a high degree of contact-induced changes under Sakha influence (Pakendorf 2009).

\subsection{Aims of this study and methodological issues}

As outlined above, the Mongolic languages, Sakha, and Lamunkhin Ėven are all typologically similar languages with morphology that should be relatively easy to copy: they all have a large amount of inflectional and derivational agglutinative morphology that is relatively unifunctional, sharply bounded, phonologically robust and relatively invariant (albeit with regular morphophonological variation), they are all practically exclusively suffixing, and they all have verb-final syntax. The contact situations, too, appear to have been comparable, involving a sociopolitically dominant language and a sociopolitically subordinate language. Thus, in accordance with the hypotheses outlined above, Sakha and Lamunkhin Ėven are expected to have copied some morphology from their dominant neighbours, and the amount and types of copied morphemes are expected to be comparable.

However, it should be noted that for all their similarities in linguistic type and in sociolinguistic contact situation, the two case studies show important differences. They differ greatly in historical depth and in the extent to which they have been the focus of linguistic research: The Sakha - Mongolic contact took place approximately 700 to 800 years ago, with no historical accounts and thus no precise knowledge of the actual sociopolitical situation. However, a vast amount of research materials exist for Sakha - extensive dictionaries, grammars, as well as detailed investigations of copied lexemes, notably Kałużyński’s (1962) investigation specifically of Mongolic copies. In contrast, the contact between speakers of Lamunkhin Ėven and Sakha is ongoing and synchronically observable, with a high level of bilingualism among Ėven speakers. However, other than my own corpus of field data, no research materials concerning this Ėven dialect are available. This difference determines the database available for this study: for the investigation of copied morphemes of Mongolic origin in Sakha, I used primarily the list of Mongolic morphemes appended in Kałużyński (1962: 69-118) as well as consulting the information on derivational suffixes in Korkina et al. 
(1982) and Xaritonov (1947). For Lamunkhin Ėven, in contrast, I was only able to identify Sakha copies in my corpus of oral narratives (and two conversations) collected between 2008 and 2012; this comprises approximately 47,000 words from 27 speakers of both sexes ranging from 11 to 78 years in age. In the examples, the speaker's name is indicated with an abbreviation followed by the text name (for Lamunkhin Ėven) and utterance number.

The different types of database that I was able to use for Sakha and Lamunkhin Ėven determine two potential sources of errors: First of all, I might be underestimating the amount of copied morphology in Lamunkhin Ėven because low-frequency items might happen to be missing from my corpus. In contrast, I might be overestimating the amount of copied morphology in this language by not being able to securely distinguish between established copies and Sakha items used in instances of code-switching where the matrix language is Sakha (cf. Gardner-Chloros 2009: 30-32, Meakins 2011: 131-133). While I agree in principle with Backus and Verschik (2012: 131) that code-switches should be studied on a par with copies, in this particular study it is desirable to exclude code-switches as much as possible, since I am comparing two different contact situations. With respect to the Mongolic-Sakha contact I can take into account only established copies, since no code-switching is possible anymore and any Mongolic code-switches that may have occurred in Sakha speech at the time of contact are ignored. This makes it desirable to restrict the Sakha items in Lamunkhin Éven to established copies as well, since inclusion of items from instances where Sakha functions as matrix language would lead to an artificial increase of copied items found in Lamunkhin Even and thus distort the results of the comparison. Frequently used criteria for established copies are that they should be used by monolingual speakers, and that they should be used relatively frequently and independently of the context (cf. Matras 2009: 106-114). However, the first criterion is impossible to apply in the Lamunkhin Ėven-Sakha contact situation, since to my knowledge all speakers of Lamunkhin Ėven (and definitely all the speakers who contributed to my corpus) are fluent in Sakha. Therefore, I had to orient myself solely by frequency of use of items, which of course depends on context and size of the corpus.

Lastly, before turning to the discussion of the copied morphemes, it is necessary to define what I consider a copied morpheme. I only consider morphemes to be copied when they can clearly be shown to stem from an external model language rather than having been inherited from an ancestor language. Furthermore, I include in my definition only morphemes that are dissociated from the model word(s) they may have been copied with and that are freely used with recipient language items (cf. Gardani 2008: 38, 2012: 73), i.e. I exclude what Kossmann (2010) calls Parallel System Borrowing. However, in contrast to Weinreich 
(1953: 31), I do not restrict my definition only to morphemes that have been copied by themselves, independently of a "carrier word" (a process called "direct borrowing" by Seifart forthc.). Thus, I count as copies all morphemes of foreign origin that are freely used with native lexemes, irrespective of whether they also occur with copied lexemes. In contrast to Gardani (2012: 74-75) I do not consider morphemes as copies only if they have maintained the meaning and function they had in the model language. Just as copied lexemes can undergo semantic shifts and functional changes in the recipient language (e.g. Sakha kuru:k 'always, often' < Russian krug 'circle'; Pakendorf and Novgorodov 2009: 507), so can copied bound morphemes.

\section{Mongolic morphemes copied into Sakha}

\subsection{Number and kinds of copied suffixes}

Kałużyński (1962) lists over 50 suffixes of presumed Mongolic origin in Sakha. However, most of these were never demonstrably productive, since Kałużyński explicitly states that they are found only with Mongolic stems or gives only examples with Mongolic stems; others are of unclear origin, with a similar suffix attested in Turkic. These morphemes therefore do not comply with my definition that copied morphology should be clearly traceable to a model language and be productively used with native lexemes. This leaves the still substantial number of 20 morphemes of Mongolic origin for which Kałużyński states that they are or were productive in Sakha. Of these 20 suffixes, 18 are derivational, comprising 11 nominalizers, four adjectivizers, two adverbializers, and one verbalizer. Only two of the 20 suffixes of Mongolic origin are inflectional, namely the 'immediate precedence' converb and a plural suffix.

While these suffixes all conform to my definition of copied morphology by occurring with native as well as Mongolic stems, not all are equally productive. In determining the productivity of suffixes I to a large extent relied on the judgments made by Kałużyński (1962) in his discussion of the copied morphemes as well as those found in the comprehensive descriptions of Sakha morphology (Xaritonov 1947, Korkina et al. 1982). In addition, I considered suffixes to be productive that are used with Russian copies, especially where these copies are clearly recent, such as xuligan 'hooligan' (a word borrowed into Russian from English (Vasmer 2008: 278), where it is first attested in 1898, cf. Oxford English Dictionary online). It is thus possible to distinguish between currently still productive and unproductive or at most marginally productive suffixes, as will be done in the following. The currently still productive suffixes comprise 10 derivational and the 
two inflectional suffixes, while the only marginally productive or unproductive suffixes comprise eight nominalizing suffixes.

\subsection{Currently still productive suffixes}

\subsubsection{Suffixes that derive nouns from verbs}

The most productive derivational suffix copied from Mongolic is $-A$ : $\check{c} \check{c} I$, a deverbal nominalizer ( $2 \mathrm{a}$ ) that is developing a function of marking habitual aspect (2b). In my corpus of Sakha oral narratives collected in 2002 and 2003 from elderly Sakha speakers, most of whom were monolingual or had at best a rudimentary command of Russian (Pakendorf 2007: 64), an example occurs with a Russian stem (hulu'spala:- 'serve in the army' < hulu'spa 'service'), clearly demonstrating the ongoing productivity of this suffix. Note that in the examples, copies from Russian and Mongolian are indicated with $\mathrm{R}$ and $\mathrm{M}$, respectively; copies from Sakha into Lamunkhin Ėven are indicated with $\mathrm{Y}$ (< Yakut).
(2a) tujgun
hulu'spa-l-a:čči-lar
Xatarhïla-p-pït-tara
excellent
service.R-VR-HAB.M-PL
go.for.a.ride-CAUS-PSTPT-3PL
'... they took the excellent soldiers (for a flight).' [YmyE_192]
(2b)

tugu tugu
what.ACC what.ACC
'What did you usually kill?' [Chir_047]
öl-ör-ö:ččču-gün-üj?
die-CAUS-HAB.M-2SG-Q

Two further copied suffixes deriving nouns from verbs (-A:hIn and -BIl) are currently still clearly productive, as shown by their occurrence with Russian stems (e.g. (3) derived from the verb hakkaista:- 'order'). As for-BIl, of the four tokens found in my corpus, two must have been derived in the 20th century because they do not occur in the major dictionary compiled by Pekarskij ([1907-1930] 1958-1959) in the final decades of the 19th century, demonstrating the ongoing productivity of this suffix. These are öröbül 'Sunday' (< örö:- 'rest a day') and

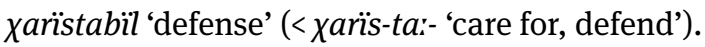

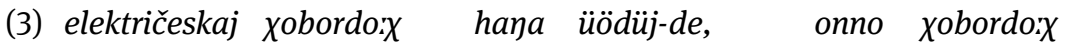
electrical.R frying-pan.R new appear-PST.3SG there frying-pan.R

hakkais-t-a:hïn-a

order.R-VR-NR.M-Poss.3sG

'Then electrical frying pans first appeared, so they ordered a frying pan (lit. the ordering of a frying pan), ....' [Efmy_402] 


\subsubsection{Suffixes deriving adjectives from verbs}

Four suffixes deriving adjectives from verbs can be found among the productive suffixes copied from Mongolic. These are -mtIA, -GAj, - $\gamma A r /-g I r$, and -(I)mtAyaj. According to Kałużyński (1962: 93), -mtIA is found mainly with Turkic stems, and even derivations from Mongolic roots must have occurred in Sakha, because these roots were first modified with Sakha reflexive and similar forms before the Mongolic adjectivizer was added, e.g. baranïmtïa 'ending easily' < bara:-n-ïmtïa [run.out/end.M-REFL.Y-ADJR.M]. There is thus little evidence that the adjectivizer ever occurred in Sakha with Mongolian roots (i.e. as "complex loanwords" (cf. Seifart forthc.)), from which it could have been extracted and productively added to Turkic roots. Rather, it might have been directly copied from Mongolian by speakers of Sakha bilingual in Mongolian. As for the suffix - GAj (with variants $-\gamma A j$ and $-\chi A j$ ), although Kałużyński (1962: 77) classifies this as 'very productive' with >250 derivations found, and Korkina et al. (1982: 165) count this among the relatively productive suffixes, it is hard to judge to what extent this is still used productively in spoken speech rather than being frozen in lexicalized items. For example, bïtarxaj 'small'(< bïtarïj- 'crumble, smash, pulverize') is likely to be fully lexicalized by now.

The suffix - $\gamma A r /-g I r$ derives adjectives from descriptive verbs. While it is classified as "relatively productive" by Korkina et al. (1982: 164), it is rarely found with Turkic stems (Kałużyński 1962: 80), probably because a large number of the descriptive verbs in Sakha were themselves copied from Mongolic. One example of an adjective derived from a Turkic stem is simigir 'having narrow eyes' < sim- 'to narrow one’s eyes’ (Kałużyński 1962: 80).

\subsubsection{Suffixes deriving verbs and adverbs}

Only one productive suffix deriving verbs from nouns and adjectives was copied from Mongolic: -(I)ryA:, which has further developed a function of deriving onomatopoetic verbs (Xaritonov 1954: 194-197). A large number of verbs derived from Turkic stems are listed in Xaritonov (1954: 145-147), such as kü:hürge:- 'consider oneself strong' < küis 'strength, force'.

Two productive adverb-deriving suffixes were copied from Mongolic: -TA, which derives multiplicatives of numerals, and -(I) ̌̌ ̌ I, which derives adverbs from verbs. The former derives multiplicatives not only from plain numerals, e.g. birde 'once' (< birr 'one'), ikkite 'twice' (< ikki 'two'), but also from derived forms (e.g. uončata 'approximately ten times' < uon-ča 'ten-approximative'). Given that no numerals or other quantifiers that in Mongolian occur with this 
suffix appear to have been copied into Sakha from Mongolian, this, too, seems likely to be a "direct copy", similar to the direct copying of ordinal prefixes from Visayan languages into Chavacano (Seifart forthc.).

As for -(I) ̌̌čI, this has undergone a slight shift in meaning, since in Mongolic it is an imperfective converb. According to Korkina et al. (1982: 350-351), this is particularly productive in poetic language, since it derives adverbs predominantly from onomatopoetic and descriptive verbs (4). It is not entirely clear to what extent this is still productive in everyday Sakha speech, since several items found in the Sakha corpus appear to be lexicalized (e.g. uhulučču 'particularly' < uhul- 'take off, remove', bulgučču 'without fail' < bulguj- 'unharness'.

(4) Хoro-čču

$$
\text { ulait-an }
$$

er-er

$e$-te

stand.tall-ADVR.M grow-PF.CVB

INCP-PRSPT

be-PST.3SG

'... she had started to shoot up, ...' [Pav95_045]

\subsubsection{Inflectional suffixes}

As mentioned above, only two inflectional suffixes were copied by Sakha from Mongolic: a plural suffix $-t(6 a-c)$ and the immediate precedence converb -A:t:

(5)

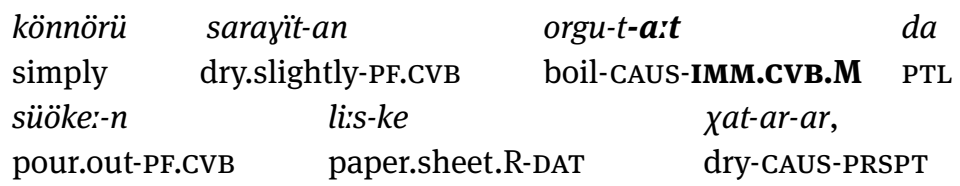

'... they simply dried it slightly, as soon as it boiled they poured it onto a sheet of paper and dried it, ...' [XatR_133]

As for the plural suffix, this attaches to nouns ending in - $n$, and is used predominantly (though not exclusively) with nouns denoting human referents. Initially, this was used to derive nouns with a collective meaning (e.g. tojon 'lord' > tojot 'gentlemen'), but the suffix later became reinforced with the Sakha (Turkic) plural suffix -LAr (Xaritonov 1947: 102-103), resulting in the modern-day suffix -ttAr. The high level of productivity of this suffix is attested to by the occurrence with a Russian noun of very recent origin (külüge:n < xuligan 'hooligan', cf. 6a) as well as with an adjective (6b) and even a particle expressing endearment (baraxsan, cf. 6c). ${ }^{2}$

2 Note that the glosses reflect a diachronic analysis to illustrate the Mongolian provenance of the suffix $t$; synchronically, $t$ Ar can be considered an allomorph of the plural suffix LAr. 
(6a) $h u-b u$ kiniler kïla:s-tara barï manna külüge:-t-ter EMPH-this 3PL class.R-POsS.3PL all here hooligan.R-PL.M-PL 'Just their class here were all hooligans.' [IvaP_312]

(6b)

$\begin{array}{llll}\text { biligin } & \text { bura:n-ïnan } & \text { bultui-r-ga } & \text { buollayïna } \\ \text { now } & \text { snow.mobile.R-INS } & \text { hunt-PRSPT-DAT } & \text { DP } \\ \text { ulaxan } & \text { iaraxa-t-tar } & \text { ba:l-lar } & \end{array}$

big heavy-PL.M-PL existence-PL

'Now they go hunting with snow-mobiles, and they're very expensive.' [LukP_107]

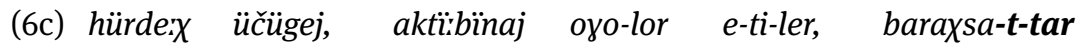
very good active.R child-PL be-PST-PL PTL-PL.M-PL 'They were very good, active kids, the dears.' [MalA_177]

The fact that one of the two inflectional suffixes that Sakha copied from Mongolic is a plural marker is in good accordance with cross-linguistic evidence (Grant 2008: 169-171; Gardani 2012). Approximately one third of the copied inflectional morphemes identified by Gardani (2012) in a large crosslinguistic sample are plural markers, making plurals the most frequently copied single category of inflectional morphology. Furthermore, structural factors appear to play a role as well, since $75 \%$ of the plural markers listed by Gardani (2012: 86-90), including the Mongolic suffix copied by Sakha, are agglutinative.

\subsection{At most marginally productive suffixes}

This category comprises eight suffixes that derive nouns from verbs. One (-ltA) is listed as 'marginally productive' by Korkina et al. (1982), while the others are either not mentioned at all $(-l,-B I r,-d A h I n,-\lg A(n),-m A r)$ or are listed among the 'frozen suffixes of Mongolic origins' ( $-m n \dot{I}$ and $-m t A)$. Nevertheless, even though they are not productive anymore, all of these suffixes conform to my criterion of copied morphemes by being found with Turkic stems, e.g. solodohun 'clearing (of a path)' < solo:- 'to clear a path' (Kałużyński 1962: 75), demonstrating that they were productive at the time of copying. Kałużyński (1962: 83) counts "many more than 150" derivations with the suffix $-l$ from both Mongolic and Turkic verbs in Pekarskij's dictionary, such as taptal 'love' < tapta:- 'to love' (Kałużyński 1962: 83-84).

Even though it is classified as fossilized, a seemingly productive derivation with the suffix - $m t A$ from a verb of Mongolic origin is found in my Sakha corpus: 
ergimte 'turnover' < ergij- 'to turn' (7). In the Sakha-Russian dictionary (Slepcov 1972: 544) this is translated only as 'surroundings'.

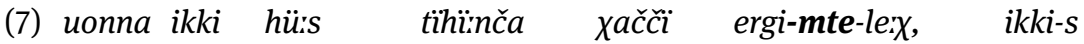
and two hundred thousand money turn-NR.M-PROP two-ORD gildija-la:X atï-hït buol-but kihi bair bu Baijaya-ttan guild-PROP sale-AGNR AUX-PSTPT man existence this Bajaga-ABL 'And there is a man here from Bajaga who became a merchant of the second guild and had a monetary turnover of 200,000.' [XatR_047]

In conclusion, the morphemes copied from Mongolic into Sakha conform to cross-linguistic expectations: a ninefold higher proportion of derivational than inflectional morphology was copied, and these derivational suffixes predominantly derive nominals (11 nominalizers and four adjectivizers; cf. Matras 2009: 210). Furthermore, one of the two inflectional suffixes is a plural marker, shown by Gardani (2012) to be the cross-linguistically most frequent type of copied inflectional suffix. Interestingly, only one quarter of the copied suffixes deriving nouns that were initially productive, as evidenced by their occurrence with Turkic stems, are still fully productive. This might possibly be due to 'competition' between suffixes that resulted from the copying of 11 morphemes with the same overall function into a language that already had similar suffixes of Turkic origin (e.g. the highly productive $-I$, which derives nouns from verbs: ölü: 'death' < öl 'die').

\section{Sakha morphemes copied into Lamunkhin Ėven}

\subsection{Number and kinds of copied suffixes}

Given the nature of the Lamunkhin Ėven data, which as described above is based solely on my corpus of narrative recordings of speakers with varying degrees of linguistic dominance in Sakha or Ėven, it is more difficult to assess the status of copied morphemes. As discussed in Section 1.3, I consider frequently occurring suffixes used by different speakers to be established copies. A complicating factor is that some suffixes occur fairly infrequently and are used predominantly or even exclusively by speakers whom I believe to be dominant in Sakha rather than Ėven. Thus, the use of such suffixes could be an indication that the matrix language is actually Sakha, and the Ėven content lexemes are code-switches into this Sakha frame. However, while this might be occasionally be true, as in (8a), where only the lexical verb roots and a particle are of Ėven origin, in other cases the Sakha verbal ending is practically the only Sakha item in the sentence (8b, c; see also 14a), making the hypothesis of Sakha as matrix language rather implausible. It 
is therefore more likely that these morphemes represent, if not fully established copies in Lamunkhin Ėven as a whole, at least ongoing copying that has begun in a subset of this speech community.

(8a) tuspa naha: ịa-jan separate.Y very.Y do.what-FUTPT.Acc.3sG.Y

bayar-ar ehni, tegeč-e-jen wish.Y-PRSPT.Y PTL live-EP-FUTPT.ACC.3SG.Y

'she very much wants to live alone, doesn't she' (said by a semi-speaker of Ėven) [beseda_0703]

(8b) derih-nek-e-s holu-ridzi run.off-COND.CVB-EP-POSS.2SG chase-ANT.CVB

dzeb-e-he-jen höp eat-EP-LIM-FUTPT.ACC.3SG.Y OK.Y 'If you run of it might chase and eat you.' [SPK_oxota_073]

(8c) nọgụụb-ba-n mai-rịdzi bọlla bej-te[n] lead.reindeer-ACC-Poss.3SG kill-ANT.CVB DP.Y man-DISTR bej-e-l-du bo:-č-e-j-egin, $\quad$ go:-li, ... man-EP-PL-DAT give-RES-EP-CONN-PRS.2SG.Y Say-IMP.2SG 'Having killed his lead reindeer, however, you give (the meat) to people, right,...'[RDA_TPK_death_115]

A further complication, to which I return after introducing the copied suffixes, concerns the number of suffixes that have been copied, since nearly all the inflectional suffixes of Sakha origin found in Lamunkhin Ėven form paradigms. However, irrespective of whether suffixes of Sakha origin represent firmly established copies or suffixes that are currently still in the process of being copied, and irrespective of their precise number, two striking facts are apparent in the Lamunkhin Ėven data: first of all, the vast bulk of copied suffixes are inflectional, with only two derivational suffixes being possible or certain copies (see below). Secondly, all these inflectional suffixes are verbal, which is very unusual from a cross-linguistic perspective (cf. Gardani 2012: 91). In the following, I will first discuss the derivational suffixes that (may) have been copied from Sakha, before turning to a discussion of the inflectional suffixes.

\subsection{Derivational suffixes}

One derivational suffix has clearly been copied from Sakha: this is the suffix -Is that derives ordinal numerals $(-(I) s$ in Sakha). Interestingly, this always 
occurs in NPs with a Russian head noun, most frequently in the context of enumerating reindeer herd brigades (stada 'herd' as an administrative unit, cf. 9a) or school classes/grades (klas). In contrast to the copied ordinal prefix in Chabacano mentioned above (Seifart forthc.), this is not a direct copy, since Sakha ordinal numerals are used as well (9b), though less frequently.

(9a)

\begin{tabular}{|c|c|c|}
\hline dzapk-ịs & & dzus:-la-n \\
\hline & & \\
\hline
\end{tabular}

'We lived in the house of the eighth brigade together (with them),' [ZAS_naled_095b]

(9b) tala bọlla mestnost' naha: ịbga, axsïs stada, Kụrụna:x there DP.Y area.R very.Y good eighth.Y herd.R K.

'That is a very good place, the eighth brigade, Kurungnax.'

[RDA_shatun_034]

A second derivational suffix of Sakha origin encountered in the Lamunkhin Ėven corpus is the suffix - $L A n$, which derives verbs from nouns. In Sakha, this can be analyzed as a combination of the general verbalizing suffix $-L A$ : with the reflexive suffix -(I)n; however, it frequently occurs with a specific meaning of acquisition in a wider sense (e.g. oyolon- 'have children' < oyo 'child', dzielen- 'found a household' < dzie 'house', idelen- 'acquire a habit, learn' < ide 'habit'). In the Lamunkhin Ėven corpus, it is found only twice, used by two different elderly speakers ${ }^{3}$ with two different verbs: trambalaniw 'I injured myself' < Russian travma 'injury', and kunalan- 'have a child' < kụa 'child' (10). Even though both instances of this suffix occur in contexts in which the matrix language is clearly Even, its infrequency in the corpus makes its status as an established or even ongoing copy rather doubtful; it is therefore not included in the overall count of copied suffixes (cf. Section 3.4).

(10) elekes kuya-lan-da:r

at.first child-VR.Y-PURP.CVB.PRFL.PL

nek-e-d-de-p

'We are about to have our first child.' [LAT_fam_hist_091a]

3 One of these two speakers probably uses Sakha more than Ėven in her daily life, since her second husband is a Sakha, and her daughter (from her first marriage) does not speak Ėven. 


\subsection{Inflectional suffixes}

As was mentioned above, the suffixes of Sakha origin are largely paradigmatic, belonging to the following four TAM paradigms: necessitative, assertive, indicative present tense, and hypothetical (used in periphrastic potential and deontic constructions); only one morpheme occurs independently of a paradigm. The copied nature of the necessitative and assertive mood is not in doubt (cf. Pakendorf 2009), since they are used in high frequency and by speakers of unquestionable dominance in Ėven. The indicative present tense and hypothetical suffixes, in contrast, are used far less frequently and only by speakers whose relative dominance of Ėven versus Sakha is unclear or certain to be weaker. As mentioned above, these might therefore possibly represent ongoing copying rather than fully established copies. However, the fact that entire paradigms are involved, and that the morphemes are used in different contexts by different speakers, makes them similar enough to established copies to be included here in the overall count.

Sakha has different subject agreement suffixes for different TAM forms: predicative person suffixes (e.g. in the necessitative mood and indicative present tense), possessive suffixes (e.g. in the assertive mood), or case-marked possessive suffixes (e.g. accusative-marked suffixes in the hypothetical mood), which have been copied with the corresponding TAM suffixes into Lamunkhin Ėven. Tables 1-4 show the Lamunkhin Ėven TAM and person-number forms encountered in the corpus in comparison to their Sakha models. It should be noted that Sakha consonants undergo bidirectional assimilation at morpheme boundaries, so that the initial consonants of the person suffixes, which in the table are given in their underlying form, are realized differently in the necessitative, assertive, and hypothetical mood (Tables 1, 2, and 4). Thus, following upon the mood-final $-\chi$, the first person suffixes are realized as - $p$ In/-pIt, the second person suffixes are realized as -kIn/-kIt, and the 3PL suffixes are realized as -tAr/-tArA/-tArIn. In contrast, the final consonant of the assertive mood suffix -TA $\chi$ is voiced before the vowel-initial suffixes of the singular subject agreement markers. Not shown in Tables 2 and 3 are the connective glides which precede the assertive and indicative present tense suffixes of Sakha origin in Lamunkhin Ėven (cf. Pakendorf 2009: 97-100).

As can be seen in Tables 2, 3, and 4, no 2PL forms of the assertive mood, indicative present tense, or hypothetical mood occur in the Lamunkhin Ėven corpus. This is not surprising given the nature of the corpus, which consists mainly of autobiographical and other narratives where reference is made to first and third persons; thus, 2PL forms are overall rare, be they of Sakha or Even origin. In addition, the pragmatic force of the assertive mood makes this a form not expected to occur with respect to the addressee (see below). 
Tab. 1: Copied paradigm of the Sakha necessitative mood in Lamunkhin Ėven

\begin{tabular}{|c|c|c|}
\hline & Lamunkhin Ėven & Sakha \\
\hline $1 \mathrm{SG}$ & $-j A k t A: k p / n$ & $-|A X t A: X-B| n$ \\
\hline $2 \mathrm{sG}$ & $-j A k t A: k k l n$ & $-I A x t A: X-G I n$ \\
\hline $3 s \mathrm{sg}$ & $-j A k t A: k$ & -IAxtA:X \\
\hline $1 \mathrm{PL}$ & $-j A k t A: k p l t$ & $-|A \chi t A: X-B| t$ \\
\hline $2 \mathrm{PL}$ & -jAktA:kklt // -jAktA:kkl-hnAn & $-I A X t A: \chi-G I t$ \\
\hline $3 \mathrm{PL}$ & $-j A k t A: k-A-l$ & $-I A X t A: X-L A r$ \\
\hline
\end{tabular}

As can be seen in the table, Lamunkhin Ėven has copied all the person-number forms of the necessitative paradigm (with the 3sG subject agreement marker being zero in both Sakha and Lamunkhin Ėven) except for the 3PL form, where the Sakha plural marker -LAr has been replaced by the Ėven plural marker $-l$ (preceded by an epenthetic vowel). The 2PL form appears to be in transition between a form with the Sakha 2PL marker - GIt (realized as -kIt) and a form with the Lamunkhin Ėven 2PL possessive marker -hnAn. This appears to be a merger between the Sakha form and the Ėven form, as witnessed by the syllable -kI- intervening between the mood and the person marker; were the Ėven 2PL possessive merely attached to the mood suffix -jAktA:k, one would expect the form -jAktA:k-A-hnAn. Two 2PL forms with the Sakha person marker occur in the corpus, both said by one speaker (e.g. 11), while the forms with the Ėven person marker were given by my main consultant during elicitation.

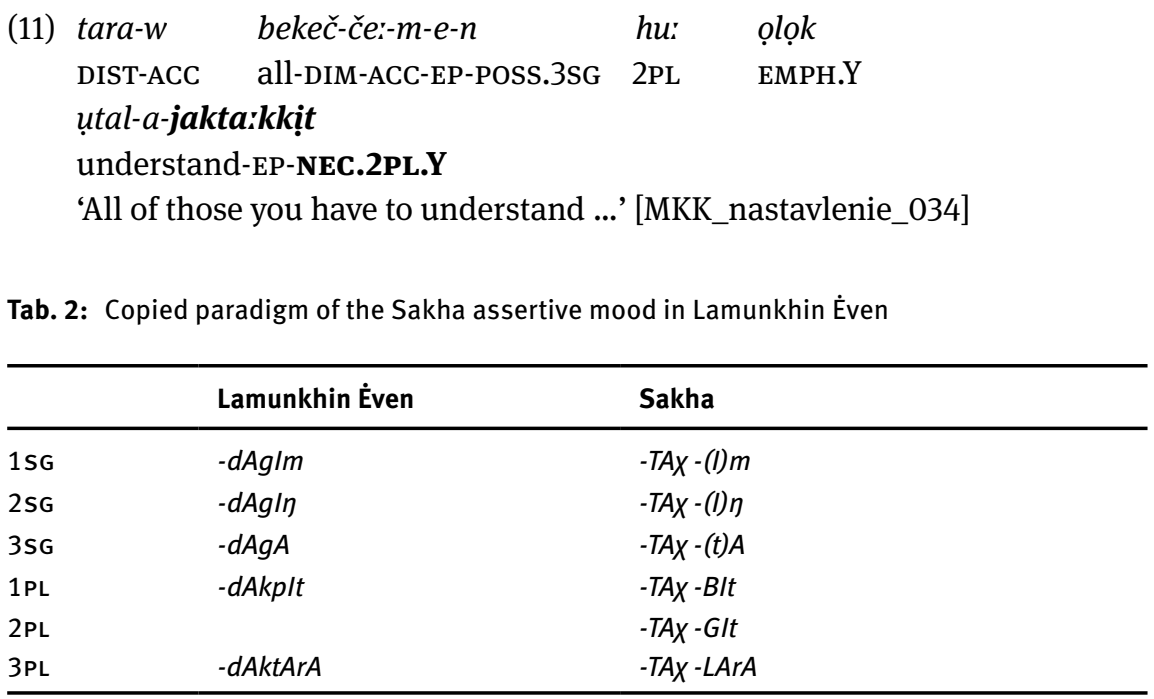


The assertive 2PL form does not occur in the corpus, and both the 2sG and the 2PL forms are elicited with difficulty. This can be explained by the pragmatic function of this mood: the assertive gives a strong nuance of emphasis to the assertion that would not be used with reference to the addressee. Thus, the 2sG forms occurring in the corpus are used with self-reference or generic reference (12); only one example in a conversation occurs with reference to the addressee.

$\begin{array}{lll}i a \text {-w-an } & \text { tiju-m } & \text { hokat-tịdzi } \\ \text { what-ACC-EP-POSS.3SG } & \text { staff-ACC } & \text { break.TRNS-ANT.CVB } \\ \text { ne:-j-er } & \text { bọl-lagịn } & \text { tadu } \\ \text { put-CONN-PRSPT.Y } & \text { AUX.Y-ASS.2sG.Y } & \text { there } \\ \text { 'And then you put the staff there after breaking it.' [RDA_TPK_death_113] }\end{array}$

It should be noted that in addition to the synthetic assertive mood forms, Lamunkhin Ėven has also copied the periphrastic construction consisting of the Sakha present participle - Ar and the Sakha auxiliary buol-in the assertive mood, as seen in the example above (12). This partly resembles Parallel System Borrowing in auxiliaries found in the Indo-Aryan language Domari and the Tibeto-Burman language Sunwar (Kossmann 2010: 470-471); however, in contrast to the cases discussed by Kossmann, in Lamunkhin Ėven the lexical verb takes the Sakha participial suffix, not an Ėven suffix. Thus, it is more than just the auxiliary that is of foreign origin.

The present participle also functions as the 3SG present tense indicative form in Sakha (see Table 3), and occurs as such in the Lamunkhin Ėven corpus (14b). Furthermore, the Sakha negative present participle -BAt is found in periphrastic negative assertive constructions ((13); cf. Pakendorf 2009). However, three out of six tokens of this morpheme occur with Sakha verb roots, and two of the Ėven verb roots found with this suffix occur in contexts that indicate a probable switch to Sakha as the matrix language. Therefore, this morpheme is not included in the overall count of copied morphemes. Nevertheless, the fact that it is in paradigmatic opposition to $-A r$ in the periphrastic assertive constructions is notable.

$\begin{array}{lllll}\text { (13) indjuk gerbe, } & \text { bi bọlla har-j-bat } & \text { bọl-lagịm } \\ \text { turkey.R name } & \text { 1SG DP.Y know-CONN-NEG.Y } & \text { AUX.Y-ASS.1SG.Y } \\ \text { iak=kọl } & \text { tarbača-maja-w } & \text { hutaku. } & \\ \text { what=INDEF } & \text { DIST.QUAL-AUG-ACC } & \text { red } \\ \text { 'It's called indjuk (turkey), and I didn't know that, right, something like that } \\ \text { big red (creature).' [AVZ_indjuk_internat_037] }\end{array}$


Tab. 3: Copied paradigm of the Sakha indicative present tense in Lamunkhin Ėven

\begin{tabular}{lll}
\hline & Lamunkhin Ėven & Sakha \\
\hline $1 \mathrm{SG}$ & $-A b I n$ & $-A-B I n$ \\
$2 \mathrm{SG}$ & $-A g I n$ & $-A-G I n$ \\
$3 \mathrm{SG}$ & $-A r$ & $-A r$ \\
$1 \mathrm{PL}$ & $-A b I t$ & $-A-B I t$ \\
$2 \mathrm{PL}$ & & $-A-G I t$ \\
3PL & $-A l l A r$ & $-A r-L A r$ \\
\hline
\end{tabular}

The Sakha present tense paradigm has different mood markers in the first and second person ( $-A$, the imperfective converb; cf. 14a) and the third person (-Ar, the present participle). The present participle is widely used in Sakha; in Lamunkhin Ėven, in addition to occurring in the indicative present tense (14b), it has also been copied in the periphrastic assertive mood forms illustrated above in (12). However, while the indicative present tense forms of Sakha origin occur with a wide variety of Ėven roots and are produced by different speakers, they are mainly found in utterances by speakers who seem dominant in Sakha rather than in Ėven. Their status as established copies in Lamunkhin Ėven as a whole is therefore rather uncertain, although they do occur in sentences in which Ėven is clearly the matrix language (14a, b).
(14a) dzui-la-j
house-LOC-PRFL.SG
hor-e-mel-mi
go-EP-DES-COND.CVB
hor-ridzi
em-e-j-egin
go-ANT.CVB
come-EP-CONN-PRS.2SG.Y
'If you want to go home you go and come back ...' [AVZ_indjuk_internat_053a]
(14b)

$\begin{array}{lll}\text { ahịkka-čaka-l } & \text { bọlla } & \text { ńamị̌ca-čaka-l-bụ } \\ \text { girl-PLEN-PL } & \text { DP.Y } & \text { reindeer.doe-PLEN-PL-ACC } \\ \text { orọn } & \text { em-e-j-er } & \text { uže } \\ \text { reindeer } & \text { come-EP-CONN-PRSPT.Y } & \text { already.R }\end{array}$
'And the girls (milk) the does; the reindeer come already.' [AXK_svatovstvo_103]

Tab. 4: Copied paradigm of the Sakha hypothetical mood in Lamunkhin Ėven

\begin{tabular}{lll}
\hline & Lamunkhin Ėven & Sakha \\
\hline $1 \mathrm{SG}$ & $-j A k p l n$ & $-I A X-B I n$ \\
$2 \mathrm{SG}$ & $-j A k k I n$ & $-I A X-G I n$ \\
$3 \mathrm{SG}$ & $-j A: g I n / /-j A n$ & $-I A X-(t) I n / /-I A n$ \\
$1 \mathrm{PL}$ & & $-I A X-B I t / n$ \\
$2 \mathrm{PL}$ & & $-I A X-G I t / n$ \\
3PL & $-j A k t A r I n$ & $-I A X-L A r I n$ \\
impersonal & $-j A k k A$ & $-I A X-G A$ \\
\hline
\end{tabular}


In Sakha, the hypothetical mood occurs in periphrastic constructions with the deontic particle na:da 'must' (copied from Russian) or the affirmative particle söp/höp 'OK', and it is in such constructions that it is found in the Lamunkhin Ėven corpus (8b). Like the indicative present tense forms, in the corpus these constructions are used by speakers whose dominance in Ėven is questionable, and some occurrences are clearly insertions of Ėven verb roots into a Sakha matrix language (8a). Nevertheless, what speaks for a copied status of these morphemes is the fact that even my primary consultant, for whom Ėven is unquestionably the dominant language, used the Sakha form when asked to translate a sentence with potential meaning into Ėven (15a). In the corpus, when it is not the Sakha form that is used, potential meanings are expressed by the indicative future (15b), a form also used by my primary consultant in her personal narrative. Thus, the Sakha hypothetical form might be preferred only when an unambiguously hypothetical reading is needed.

(15a) ńarị ahịkan-dụ oj-ụ em-u-jen höp

man girl-DAT clothes-ACc come-CAUS-FUTPT.ACc.3sG.Y OK.Y

'The man might bring clothes for the girl.'

[IVK_S_DesignativeA27a]

(15b)

$\begin{array}{llll}\begin{array}{l}\text { bo:del-dzi } \\ \text { leg-INS.PRFL.SG }\end{array} & \begin{array}{l}\text { to:-dzi-nni } \\ \text { step.on-FUT-2SG }\end{array} & \begin{array}{l}\text { e-le } \\ \text { PROX-LOC }\end{array} & \begin{array}{l}\text { hergi-li } \\ \text { bottom-PROL }\end{array} \\ \begin{array}{l}\text { hukel-lek-e-n } \\ \text { slip.off-COND.CVB-EP-POSS.3SG }\end{array} & \\ \text { 'you might step on it if it slips off.' [KNK_eksponat_198] }\end{array}$

In addition to these paradigmatically structured suffixes, one further inflectional suffix of Sakha origin occurs in the Lamunkhin Even corpus. This is the perfective (sequential) converb - $A n$, which occurs in the corpus eleven times in utterances by five different speakers (though predominantly in use by one speaker). As in Sakha, it occurs as an affirmative answer to polar questions (16a). Furthermore, in one instance it appears to have been used with a meaning of reason, a function common in Sakha, though the speaker corrected herself and gave an Ėven finite construction instead (16b). The fact that this suffix is used mostly by one speaker (who is married to a Sakha and switched to Sakha a lot), and that a speaker trying very hard to speak good Ėven corrected herself, might be indications that this suffix has not yet entered Lamunkhin Ėven as an established or even ongoing copy; it will therefore not be included in the final count of copied suffixes. 
(16a)

$\begin{array}{ll}\text { mut } & \text { itti--wu- } t \\ 1 \mathrm{PL} & \text { face-ACC-Poss.1PL }\end{array}$

'Do they see our faces?'

ič-e-j-en

See-EP-CONN-PF.CVB.Y

'Yes, they do.' [beseda_250-251]

(16b)

\begin{tabular}{|c|c|c|c|}
\hline $\begin{array}{ll}\text { Emčeni } & \text { emie } \\
\text { NAME } & \text { also.Y }\end{array}$ & \multicolumn{2}{|c|}{$\begin{array}{l}h o ̣ y-a-l-d a-j \\
\text { cry-EP-INCH-PURP.CVB-PRFL.SG }\end{array}$} & $\begin{array}{l}\text { nek-če, } \\
\text { do-PF.PTCP }\end{array}$ \\
\hline kụa-ji & ọttọn & mụla:-j-an & mụla:n-ča \\
\hline $\begin{array}{l}\text { child-PRFL.SG } \\
\text { no:-ji }\end{array}$ & DP.Y & pity-CONN-PF.CVB.Y & pity-PF.PTCP \\
\hline
\end{tabular}

'Emcheni was about to cry again, because he pitied his child, his younger brother.' [KKK_Emcheni_128]

\subsection{Separate or joint copying of TAM and subject agreement suffixes?}

The paradigmatic nature of the suffixes of Sakha origin in Lamunkhin Ėven complicates the count of copied suffixes. The question is whether the different TAM suffixes were copied separately from the subject agreement suffixes, or whether the different person-number forms were copied as a whole (as depicted in the tables above). It is quite plausible that in Sakha the individual suffixes are perceived as separate morphemes by speakers, since they all occur in various contexts. Thus, for instance, the assertive mood marker -TA $\chi$ also occurs in the conditionaltemporal mood, where it takes a different set of person markers (e.g. kepse:-texpine 'when/if I tell'). The necessitative mood marker can be analyzed in Sakha as a fusion of the future participle -IA $\chi$ plus the proprietive -LA: $\chi$ (with the initial [1] of the proprietive assimilating to the final [ $\chi$ ] of the future participle), both of which occur separately in high frequency: for example, the future participle occurs in the indicative future tense with possessive person markers (il-ïay-ïm 'I will take') and, as seen in Table 4, in the hypothetical mood, where it takes accusative-marked possessive suffixes as subject agreement markers.

In Lamunkhin Ėven, however, the case for individual perception of these morphemes is not as easily made. On the one hand, the subject agreement markers do recur - there is no distinction in Sakha between the predicative and possessive suffixes for 1PL and 2PL, which are both -BIt and -GIt, respectively; these forms (at least the 1PL form) occur in the necessitative and assertive mood 
and the indicative present tense (cf. Tables 1-3). Furthermore, in the 1sG and 2sG the predicative suffixes and the accusative-case-marked possessive suffixes are homophonous (-BIn and -GIn, respectively), so that these suffixes recur in the necessitative and hypothetical mood and the indicative present tense. On the other hand, the TAM markers do not occur independently of the copied paradigms in Lamunkhin Ėven. Since the necessitative meaning cannot be derived compositionally from the meaning of the future participle and the proprietive, it is unlikely that $-j A k$ and $-t A: k$ were copied as separate morphemes; rather, -jAktA:k as a whole can be assumed to have been copied as the necessitative mood marker. Thus, one cannot assume that -jAk found in the hypothetical mood is a recurrent form of $-j A k$ as it occurs in the necessitative. Furthermore, while the mood marker recurs throughout the paradigm for the necessitative and the assertive mood, as mentioned above the indicative present tense marker in Sakha is split between the imperfect converb - $A$ for the first and second person and the present participle for the third person (with all persons taking predicative subject agreement marking, which is zero for 3sG), making it more plausible that the different person-number forms were copied in their entirety.

A strong indication that the TAM and person markers of the hypothetical paradigm were copied as a whole comes from the existence of both the full 3SG form -jA:gIn and the contracted form -jAn in Lamunkhin Even. While in Sakha the contraction is due to a frequent morphophonological process in which intervo-

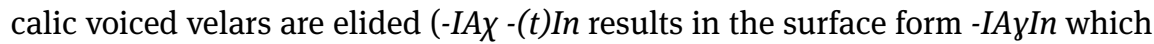
results in $-I A n)$, such elision does not take place in Lamunkhin Ėven. Therefore, both the full and the contracted form must have been copied from Sakha.

In contrast, an argument in favor of the separate perception and copying of the TAM and person suffixes might be the existence of the necessitative 3PL with Sakha person marking (cf. Table 1). This indicates that for this mood, at least, the TAM and the person suffixes are indeed separate entities. However, it is quite likely that the Sakha TAM-person suffixes were copied as a whole and only later were analyzed as separate morphemes, leading to the replacement of the Sakha 3PL suffix in the necessitative mood. An argument in favor of this scenario is the variation still observable in the 2PL necessitative; similarly, in attempts to elicit 2PL assertive forms, both Sakha (-dAkkIt) and Ėven (-dAgIhnAn) subject agreement forms were given. Therefore, for the purposes of this paper I will assume that the Sakha mood forms were copied as a whole in Lamunkhin Even, comprising both TAM and person suffixes.

Thus, a total of 21 inflectional suffixes of Sakha origin are found in the corpus of Lamunkhin Ėven, in contrast to one clearly copied derivational suffix. While it is quite probable that the forms missing in Tables 3 and 4 have also entered Lamunkhin Ėven and merely do not occur in the somewhat restricted narrative 
corpus, I can here only count those forms that are attested. As will be discussed in the following, the copies in Lamunkhin Ėven differ strikingly from those in Sakha discussed in Section 2 above.

\section{Discussion}

In this paper I set out to investigate whether languages that are structurally congruent and that have phonologically salient and syllabic, sharply bounded, relatively unifunctional, categorially clear morphology would more readily copy affixes, as predicted in (1) above. I also aimed at elucidating whether such a contact situation would lead to the copying of derivational rather than inflectional morphology, whether morphemes with a specific or pragmatically salient meaning would be more likely to be copied than morphemes with a general meaning, and whether copied morphemes would be paradigmatically and syntagmatically structured. The data can be summarized as follows:

Tab. 5: Summary of copied suffixes in Sakha and Lamunkhin Ėven

\begin{tabular}{lll}
\hline & Sakha < Mongolic & Lamunkhin Ėven < Sakha \\
\hline & $\begin{array}{l}11 \text { nominalizers (of which } 7 \text { not } \\
\text { productive anymore) }\end{array}$ & \\
Derivational & $\begin{array}{l}\text { 4djectivizers } \\
2 \text { adverbializers } \\
1 \text { verbalizer }\end{array}$ & 1 ordinal suffix \\
\hline & & \\
Inflectional & $\begin{array}{l}1 \text { plural (restricted use) } \\
1 \text { converb }\end{array}$ & $\begin{array}{l}5 \text { forms of necessitative } \\
5 \text { forms of assertive } \\
5 \text { forms of indicative present tense } \\
6 \text { forms of hypothetical }\end{array}$ \\
\hline
\end{tabular}

Several noteworthy issues are apparent from this table. First of all, both Sakha and Lamunkhin Ėven have copied a large number of suffixes, 20 and 22, respectively. ${ }^{4}$ This is far more than attested in most other cases of large-scale morphological copying: for example, none of the languages of Arnhem Land, Australia, has copied more than eight suffixes (Heath 1978: 68-118), and the Spanish-based creole Chabacano has copied six prefixes and two suffixes from

4 In Lamunkhin Ėven, the number is likely to be even larger, since only those forms attested in the corpus were included in the count. 
the Philippine language Hiligaynon, with another prefix of unclear origin (Steinkrüger 2003: 257-259) - though note that the Arawakan language Resígaro has copied 36 morphemes from Bora (Seifart 2012: 482). This confirms the hypothesis laid out in Section 1.1, namely that structural congruence and agglutinative morphology facilitate morpheme copying, possibly enhanced further when the contact situation is asymmetric. Resígaro and Bora, too, have congruent agglutinative morphology, and the model language Bora was sociopolitically dominant over Resígaro (Seifart 2012: 477-478).

Secondly, while Sakha and Lamunkhin Ėven are similar as regards the number of copied morphemes, they are strikingly different with respect to the type of copied morphology: Of the 20 suffixes copied from Mongolic into Sakha, 18 (90\%) are derivational and two (10\%) are inflectional. Lamunkhin Ėven, in contrast, copied 22 suffixes from Sakha, of which 21 are inflectional (95.5\%) and only one (4.5\%) is derivational. Thus, Sakha conforms to cross-linguistic expectations, but Lamunkhin Even doesn't - even though the morphosyntactic structures and sociolinguistic parameters of the two contact situations are comparable, with a sociopolitically subordinate recipient language copying morphemes from a dominant language (Section 1.2.1 and 1.2.2). Furthermore, the entire inflectional morphology copied by Lamunkhin Ėven is verbal. This contrasts strongly with other cases of large-scale morphological copying, where the copied inflectional morphology is predominantly nominal; copying of verbal inflection is cross-linguistically exceedingly rare (Gardani 2012: 91). The fact that the copied suffixes in Lamunkhin Ėven are mainly from the domain of modality (necessitative, assertive, and hypothetical) corroborates the findings of Matras (2007: 46) that modality is more likely to be affected by contact than aspect/aktionsart, and that tense is the least likely to undergo contact-induced changes. Furthermore, the copying of these mood paradigms conforms with the expectation raised by Backus and Verschik (2012: 140) that the more semantically and pragmatically salient an item, the more likely it is to be copied as a form-meaning unit (also termed global copying [Johanson 1999: 41] or copying of matter [Matras and Sakel 2007: 829]).

Both Sakha and Ėven confirm Seifart's (2012) hypothesis that copied morphemes are more likely to come from paradigmatically or syntagmatically structured subsystems: in Sakha, 15 of the 20 copied morphemes derive nominals (nouns and adjectives) from verbs, while in Lamunkhin Ėven the copied morphemes form clear paradigms. Of course, the paradigmatic structure of some of these copies (the indicative present tense and the hypothetical mood) was used in support of counting them as copies, resulting in a circular argument. Nevertheless, the copied necessitative and assertive paradigms are clearly established in Lamunkhin Ėven as a whole and thus support the hypothesis. 
How can we explain the striking difference between Sakha and Lamunkhin Ėven? Structural factors can be excluded, since in both Sakha and Lamunkhin Ėven the structure of the recipient language is congruent with that of the model language, and morphemes are phonologically salient and syllabic (i.e. independently pronounceable), categorially clear, and relatively unifunctional (that is, they are not portmanteau morphemes). Furthermore, in both Mongolic languages and in Sakha the bare verb root functions as a 2sG imperative, so that verb stems in both model languages are sharply bounded. All of these factors should have made it equally easy for Sakha to copy verbal inflectional suffixes from Mongolic as Lamunkhin Ėven did from Sakha - but this did not happen.

The explanation must therefore be sought elsewhere, notably in the contact situation. Although the two contact situations appear superficially similar (with a sociopolitically dominant model language and a subordinate recipient language), differences may exist in the actual intensity of the contact. Indeed, while there are no direct observations or historical data on the Sakha-Mongolic contact situation, molecular anthropological data show no evidence for intimate contact between the Sakha ancestors and the Mongols: there are no signs of admixture between the two in the paternal line, and hardly any evidence for admixture in the maternal line (Pakendorf et al. 2006). In contrast, the Ėven-Sakha contact taking place in Sebjan-Küöl is intense, with extensive bilingualism and strong cultural pressure from Sakha. Furthermore, there is genetic evidence of Sakha paternal admixture in Lamunkhin Ėvens that is indicative of close social and physical interactions that go back several generations (Duggan et al. 2013). Thus, the prehistoric contact between the ancestors of the Sakha and the speakers of Mongolic languages appears to have been a lot less intimate than the ongoing contact between Sakha and Lamunkhin Ėven. This is corroborated further by the large number of mixed Sakha-Ėven marriages existing in Sebjan-Küöl today. For Resígaro, too, close contact with speakers of Bora has been documented, and it is probable that Resígaros and Boras intermarried regularly (Seifart 2012: 478). Thus, it seems that close contact at an intimate level might be a further factor facilitating not only large-scale copying of morphology, but especially of inflectional morphology (cf. Gardani 2008: 88).

\section{Conclusions}

The comparison between morphological copies in Sakha and Lamunkhin Ėven has shown that structural factors alone do not determine the outcome of contact. While the typological congruence between the model and the recipient languages in both case studies, and the agglutinative structure of the languages, may 
well have been decisive in producing the striking amount of copied suffixes, the differences in outcome can only be explained by differences in the sociocultural aspects of the contact situation. This is in good accordance with Thomason and Kaufman's statement that “it is the sociolinguistic history of the speakers, and not the structure of their language, that is the primary determinant of the linguistic outcome of language contact” (1988: 35).

What is intriguing is the evidence indicating that the Sakha-Ėven contact situation is biased towards Sakha men marrying Even women. This is reminiscent of Copper Island Aleut, which emerged in a community of mixed parentage, where the men were of Russian origins and the women were Aleuts. Copper Island Aleut is famous for its mixture of Russian verbal inflection and Aleut lexicon and noun structure (Thomason 1997) - and while Lamunkhin Ėven is still very far from having replaced its rich verbal inflection with Sakha morphology, it is nevertheless noteworthy that it is precisely the verbal inflection that has been or is being copied. While it is unclear why specifically the copying of verbal inflectional morphology would be favored in these communities with mixed households, one could speculate that in mixed households where the father stems from the socially dominant group, it is his language that predominates. Since the verbal morphology provides the predicative frame of the utterance, bilingual speakers who are dominant in their father's language would be inserting lexemes from their mother's language into this frame. This might open the door for verbal morphemes from the paternal language to enter the maternal language. ${ }^{5}$

\section{Acknowledgments}

I thank Frank Seifart, Martine Robbeets, and Francesco Gardani for pertinent comments on a draft of this paper; all remaining errors are mine alone.

\section{Abbreviations}

$\begin{array}{ll}\text { ABL } & \text { ablative } \\ \text { ACC } & \text { accusative } \\ \text { ADJR } & \text { adjectivizer }\end{array}$

5 It is true that Michif, a mixed language that also emerged in a community of mixed ancestry, uses the verbal morphology of the mother's language, Cree. However, Michif differs from Copper Island Aleut and Lamunkhin Ėven in that the entire VP is of Cree origin, i.e. the verb stem plus the inflection. 


\begin{tabular}{|c|c|}
\hline ADVR & adverbializer \\
\hline AGNR & agent nominalizer \\
\hline ANT & anterior \\
\hline ASS & assertive \\
\hline AUG & augmentative \\
\hline AUX & auxiliary \\
\hline CAUS & causative \\
\hline COND & conditional \\
\hline CONN & connective glide \\
\hline CVB & converb \\
\hline DAT & dative \\
\hline DES & desiderative \\
\hline DIM & diminutive \\
\hline DIST & distal demonstrative \\
\hline DISTR & distributional \\
\hline DP & discourse particle \\
\hline ЕMPH & emphatic \\
\hline $\mathrm{EP}$ & epenthetic vowel \\
\hline FUT & future \\
\hline FUTPT & future participle \\
\hline HAB & habitual \\
\hline IMM & immediate precedence \\
\hline IMP & imperative \\
\hline IMPF & imperfective \\
\hline $\mathrm{INCH}$ & inchoative \\
\hline INCP & inceptive \\
\hline INDEF & indefinite \\
\hline INS & instrumental \\
\hline LIM & limitative \\
\hline LOC & locative \\
\hline M & Mongolic copy \\
\hline NEC & necessitative \\
\hline NEG & negative \\
\hline NFUT & non-future \\
\hline NR & nominalizer \\
\hline ORD & ordinal \\
\hline $\mathrm{PF}$ & perfective \\
\hline PL & plural \\
\hline PLEN & plenitude \\
\hline POSS & possessive \\
\hline
\end{tabular}




$\begin{array}{ll}\text { PRFL } & \text { reflexive possessive } \\ \text { PROG } & \text { progressive } \\ \text { PROL } & \text { prolative } \\ \text { PROP } & \text { proprietive } \\ \text { PROX } & \text { proximal demonstrative } \\ \text { PRS } & \text { present } \\ \text { PRSPT } & \text { present participle } \\ \text { PST } & \text { past } \\ \text { PSTPT } & \text { past participle } \\ \text { PTCP } & \text { participle } \\ \text { PTL } & \text { particle } \\ \text { PURP } & \text { purposive } \\ \text { Q } & \text { interrogative clitic } \\ \text { QUAL } & \text { qualitative } \\ \text { R } & \text { Russian copy } \\ \text { REFL } & \text { reflexive } \\ \text { RES } & \text { resultative } \\ \text { SG } & \text { singular } \\ \text { SIM } & \text { simultaneous } \\ \text { TRNS } & \text { transitive } \\ \text { VR } & \text { verbalizer } \\ \text { Y } & \text { Sakha (Yakut) copy }\end{array}$

\section{References}

Alekseev, Anatolij N. 1996. Drevnjaja Jakutija - Železnyj vek i èpoxa srednevekov'ja [Ancient Yakutia: The Iron Age and the Medieval Epoch]. Novosibirsk: Izdatel'stvo Instituta Arxeologii i Etnografii SO RAN.

Backus, Ad \& Anna Verschik. 2012. Copiability of (bound) morphology. In Lars Johanson \& Martine Robbeets (eds.), Copies versus cognates in bound morphology, 123-149. Leiden \& Boston: Brill.

Burykin, Aleksej A. 2004. Jazyk maločislennogo naroda v ego pis'mennoj forme.

Socio-lingvističeskie i sobstvenno lingvističeskie aspekty [The language of a minority peoples in its written form. Sociolinguistic and linguistic aspects]. St. Petersburg: Peterburgskoe Vostokovedenie.

Duggan, Ana T, Mark Whitten, Victor Wiebe, Michael Crawford, Anne Butthof, Victor Spitsyn, Sergey Makarov, Innokentiy Novgorodov, Vladimir Osakovsky \& Brigitte Pakendorf. 2013. Investigating the prehistory of Tungusic peoples of Siberia and the Amur-Ussuri region with complete mtDNA genome sequences and Y-chromosomal markers. PloS one 8(12). e83570. doi:10.1371/journal.pone.0083570. 
Gardani, Francesco. 2008. Borrowing of inflectional morphemes in language contact. Frankfurt am Main: Peter Lang.

Gardani, Francesco. 2012. Plural across inflection and derivation, fusion and agglutination. In Lars Johanson \& Martine Robbeets (eds.), Copies versus cognates in bound morphology, 71-97. Leiden \& Boston: Brill.

Gardner-Chloros, Penelope. 2009. Code-switching. Cambridge: Cambridge University Press.

Gogolev, Anatolij I. 1993. Jakuty. Problemy ètnogeneza i formirovanija kul'tury [The Yakuts. Problems of their ethnogenesis and the formation of their culture]. Yakutsk: Izdatel'stvo JaGU.

Grant, Anthony. 2008. Contact-induced change and the openness of "closed" morphological systems: Some cases from Native America. Journal of Language Contact 2(1). 165-186.

Heath, Jeffrey. 1978. Linguistic diffusion in Arnhem Land. Canberra: Australian Institute of Aboriginal Studies.

Janhunen, Juha. 1998. Ethnicity and language in prehistoric Northeast Asia. In Roger Blench \& Matthew Spriggs (eds.), Archaeology and language II: Correlating archaeological and linguistic hypotheses, 195-208. London \& New York: Routledge.

Johanson, Lars. 1999. The dynamics of code-copying in language encounters. In Bernt Brendemoen, Elizabeth Lanza \& Else Ryen (eds.), Language encounters across time and space. Studies in language contact, 37-62. Oslo: Novus forlag.

Kałużyński, Stanisław. 1962. Mongolische Elemente in der jakutischen Sprache. Warszawa: Państwowe Wydawnictwo Naukowe; 'S-Gravenhage: Mouton \& Co.

Korkina, Evdokija I, Elizaveta I. Ubrjatova, Luka N. Xaritonov \& N. E. Petrov. 1982. Grammatika sovremennogo jakutskogo literaturnogo jazyka. Fonetika i morfologija [A grammar of the modern Yakut literary language. Phonetics and morphology]. Moskva: Izdatel'stvo 'Nauka'.

Kossmann, Maarten. 2010. Parallel System Borrowing: Parallel morphological systems due to the borrowing of paradigms. Diachronica 27(3). 459-487.

Matras, Yaron. 2007. The borrowability of structural categories. In Yaron Matras \& Jeanette Sakel (eds.), Grammatical borrowing in cross-linguistic perspective, 31-73. Berlin \& New York: Mouton de Gruyter.

Matras, Yaron. 2009. Language contact. Cambridge: Cambridge University Press.

Matras, Yaron \& Jeanette Sakel. 2007. Investigating the mechanisms of pattern replication in language convergence. Studies in Language 31(4). 829-865.

Meakins, Felicity. 2011. Case-marking in contact. The development and function of case morphology in Gurindji Kriol. Amsterdam \& Philadelphia: John Benjamins.

Pakendorf, Brigitte, Innokentij N. Novgorodov, Vladimir L. Osakovskij, Al'bina P. Danilova, Artur P. Protod'jakonov \& Mark Stoneking. 2006. Investigating the effects of prehistoric migrations in Siberia: Genetic variation and the origins of Yakuts. Human Genetics 120(3). 334-353.

Pakendorf, Brigitte. 2007. Contact in the prehistory of the Sakha (Yakuts): Linguistic and genetic perspectives. Utrecht: LOT.

Pakendorf, Brigitte. 2009. Intensive contact and the copying of paradigms: An Ėven dialect in contact with Sakha (Yakut). Journal of Language Contact 2(2). 85-110.

Pakendorf, Brigitte \& Innokentij N. Novgorodov. 2009. Loanwords in Sakha (Yakut), a Turkic language of Siberia. In Martin Haspelmath \& Uri Tadmor (eds.), Loanwords in the world's languages: A comparative handbook, 496-524. Berlin: De Gruyter Mouton. 
Pekarskij, Eduard K. 1958/1959. Reprint. Slovar' jakutskogo jazyka [Dictionary of the Yakut language]. Yakutsk: Jakutskij filial Akademii nauk SSSR. Original edition, place and publisher unknown, 1907-1930.

Poppe, N. N. 1954. Grammar of written Mongolian. Wiesbaden: Harrassowitz.

Russian census. 2010. http://www.perepis-2010.ru/results_of_the_census/results-inform. php. Accessed 16.10.2012.

Seifart, Frank. 2012. The principle of morphosyntactic subsystem integrity in language contact. Evidence from morphological borrowing in Resígaro (Arawakan). Diachronica 29(4). 471-504.

Seifart, Frank. forthc. Direct and indirect affix borrowing. Language.

Slepcov, P. A. (ed.). 1972. Jakutsko-Russkij Slovar' [Yakut-Russian dictionary]. Moscow: Izdatel'stvo "Sovetskaja Ėnciklopedija”.

Steinkrüger, Patrick. 2003. Morphological processes of word-formation in Chabacano (Philippine Spanish Creole). In Ingo Plag (ed.), Phonology and morphology of creole languages, 253-268. Tübingen: Niemeyer.

Thomason, Sarah G. 1997. Mednyj Aleut. In Sarah G. Thomason (ed.), Contact languages. A wider perspective, 449-468. Amsterdam \& Philadelphia: John Benjamins.

Thomason, Sarah G. \& Terrence Kaufman. 1988. Language contact, creolization, and genetic linguistics. Berkeley: University of California Press.

Vasmer, Max. 2008. Russisches etymologisches Wörterbuch, III Band. Heidelberg: Winter.

Weinreich, Uriel. 1953. Languages in contact - findings and problems. New York: Linguistic Circle of New York.

Wilkins, David P. 1996. Morphology. In Hans Goebl, Peter H. Nelde, Zdeněk Starý \& Wolfgang Wölck (eds.), Contact linguistics. An international handbook of contemporary research, 109-117. Berlin: Walter de Gruyter.

Xaritonov, Luka N. 1947. Sovremennyj jakutskij jazyk. Čast' pervaja: fonetika i morfologija [The modern Yakut language. Part I: Phonetics and morphology]. Yakutsk: Naučno-Issledovatel'skij Institut jazyka, literatury i istorii JaASSR.

Xaritonov, Luka N. 1954. Tipy glagol'noj osnovy v jakutskom jazyke [Types of verb roots in Yakut]. Moskva, Leningrad: Izdatel'stvo Akademii Nauk SSSR. 


\section{Appendix: Mongolic model forms for the suffixes copied into Sakha}

In the following table I list the suffixes that were copied into Sakha (column "copy") in the order of discussion in the text, together with the Mongolic model form (column "model”) proposed by Kałużyński (1962: 69-118), the Mongolic function as described by Poppe (1954), and the page number(s) in Kałużyński 1962 on which the given suffix is discussed (column 'reference').

As will be seen from a comparison of the model with the copy, some of the latter have undergone substantial phonological changes - far more than found for the Sakha copies in Lamunkhin Ėven discussed in Section 3. This is probably because of the long period of time that has elapsed since the Mongol-Sakha contact, as opposed to the still ongoing Sakha-Lamunkhin Ėven contact.

\begin{tabular}{|c|c|c|c|}
\hline Copy & Model & Mongolic function & Reference \\
\hline -A:ččl & -yači (>-a:či) & deverbal nominalizer & 70 \\
\hline$-A: h \ln$ & -yasun (>-a:sun) & deverbal nominalizer & $70-71$ \\
\hline$-B I I$ & $-\gamma u l(>-a-\gamma u l>a ' u l>-u: l)$ & deverbal nominalizer & $72-73$ \\
\hline$-m t I A$ & -mtayu (-mtu:) & deverbal adjectivizer & $93-94$ \\
\hline$-G A j$ & $-G A j$ & $\begin{array}{l}\text { deverbal and denominal } \\
\text { nominalizer }\end{array}$ & $76-78$ \\
\hline -yar/-glr & $-y A r /-g \mid r$ & $\begin{array}{l}\text { deverbal nominalizer and } \\
\text { adjectivizer }\end{array}$ & $79-80$ \\
\hline -(I)mtAyaj & -mtayaj & deverbal nominalizer & 92 \\
\hline -(I)ryA: & -rqa & denominal verbalizer & $105-106$ \\
\hline$-\mathrm{TA}$ & - ta & multiplicative numerals & 118 \\
\hline$-(I) \check{c ̌ c ̌ l ~}$ & 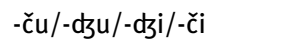 & imperfective converb & $112-113$ \\
\hline$-\mathrm{t}$ & $-d$ & plural suffix & $116-118$ \\
\hline$-A: t$ & $-\operatorname{yad}(>-\mathrm{a}: \mathrm{d})$ & perfective converb & 112 \\
\hline$-\operatorname{lt} A$ & -Ita & deverbal nominalizer & $86-87$ \\
\hline-1 & -1 & deverbal nominalizer & $83-84$ \\
\hline$-B \mid r$ & -bUrl & deverbal nominalizer & $73-74$ \\
\hline$-d A h l n$ & -dasun & deverbal nominalizer & 75 \\
\hline$-\lg A(n)$ & -lya(n) & deverbal nominalizer & $85-86$ \\
\hline$-m A r$ & -mar & deverbal nominalizer & $89-90$ \\
\hline -mńl & -mdzi & deverbal nominalizer & $90-91$ \\
\hline$-m t A$ & $-m t a$ & deverbal nominalizer & $91-92$ \\
\hline
\end{tabular}


Brought to you by | De Gruyter / TCS Authenticated

Download Date | 11/24/14 6:12 PM 